\title{
Preparation of Titanium Dioxide Nanoparticles and PolyVinyl Pyrrolidone Polymer Films as Antibacterial, Antibiofilm against Pathogenic Bacteria on Different Surfaces
}

\author{
${ }^{1}$ Jehan Abdul Sattar Salman, ${ }^{2}$ Mahasin F. Hadi AL-Kadhemy ${ }^{*}$, ${ }^{3}$ Samara A. \\ Madhloom \\ ${ }^{2}$ AL-Mustansiriyah University - College of Science - Department of Biology \\ ${ }^{2,3}$ AL-Mustansiriyah University - College of Science - Department of Physics \\ Baghdad, IRAQ \\ *Corresponding Author: drmahasinf@yahoo.com \\ Received: 10 February 2017 Revised manuscript received: 22 Nov $2017 \quad$ Accepted: 27 Nov 2017
}

\begin{abstract}
In this paper, the structural properties that included X-ray diffraction (XRD) of Polyvinyl Pyrrolidone (PVP) and PVP with titanium dioxide nanoparticles have studied. PVP still appeared amorphous structure in spite of presence of titanium dioxide nanoparticle with crystalline form. The films of pure PVP and PVP with titanium dioxide nanoparticle have been prepared by casting method and used in covering glass plates and plastic to study the effect of these films on growth of bacteria. The antibacterial effect against Staphylococcus aureus and Escherichia coli has been tested. In this study the prepared films had antibacterial effect on plastic and glass plates, the reduction of bacterial growth percentage for PVP films on plastic and glass plates reached to $60.89 \%$ and $62.5 \%$ against $S$. aureus and $49 \%, 51 \%$ against E. coli, respectively. Whereas the percentage for prepared films from a mixture of PVP with titanium dioxide nanoparticle on plastic and glass plates reached $89.42 \%$ and $86 \%$, respectively against $S$. aureus and $100 \%, 69 \%$ against E.coli. Antibiofilm effect of PVP with titanium dioxide nanoparticle against pathogenic bacteria on catheters was studied for (4) weeks. PVP with titanium dioxide nanoparticle films had the ability to inhibit biofilm formation for pathogenic bacteria on catheters, the inhibition of biofilm percentage reached to $83.97 \%$ against S.aureus and $65.3 \%$ against E.coli after fourth week of storage.
\end{abstract}

Keywords: (PVP) Polymer; $\mathrm{TiO}_{2}$ nanoparticles; Antibacterial Activity; Antibiofilm; Staphylococcus aureus and Escherichia coli; catheters.

\section{INTRODUCTION}

Polyvinyl Pyrrolidone (PVP) is a polymer with different grades according to its molecular weight. It applicable to use as a binder in the tablet formulations.
The wet granulation for PVP with a molecular weights of 25,000 to 90,000 compared to other binders, generally gives harder granulates with very good flow ability, higher binding and low friability (Chowhan, et al., 1992). Also, to enhance these properties, PVP 
increases the dissolution of the active ingredient. The tablets of Acetaminophen (paracetamol) that formulate with ratio $4 \%$ of PVP with molecular weight 90,000 used as binder released the drug more quickly than tablets with gelatin or hydroxypropyl cellulose as binder, this mean the povidone tablets were harder (Jun et al., 1989). The same results were obtained with ratio 0.6 or $1.0 \%$ of PVP $(\mathrm{Mw}$ 90,000) or hydroxypropyl cellulose (Sinchalpanid, 1993). A lot of the active substances have poor aqueous solubility because they have limited bioavailability. The easy way to enhance the bioavailability of an active substance by improving its dissolution by adding solubilizing agents, such as the soluble PVP grades. These water-soluble complexes with many active substances and increase the bio availability and a large number of organic solvents; such as alcohols, amines, acids, chlorinated hydrocarbons, lactones and amides. In addition to, polymer is insoluble in common Esters, hydrocarbons, ethers and ketones (Basf, 2009). All grades of povidone can be used as hydrophilic polymers which physically stabilize suspensions. The protective colloids is considered themost important and primary function in all suspensions, that hydrophilize the individual solid particles and sterically separate them. This led to increase the volume of any sediment and makes it is very easy to redisperse by shaking. Also Povidone prevents dissolved portion of active substance from crystallizing out by forming soluble complexes with it (Kadajji\& Mitrevej, 2011).

Titanium dioxide nanoparticles have become a new generation of advanced materials because their novel and interesting optical, dielectric, and photocatalytic properties from size quantization (Alivisatos, 1996). Titanium dioxide $\left(\mathrm{TiO}_{2}\right)$ is a photo catalyst and widely utilize as a selfdisinfecting and self-cleaning material for surface coating used in many applications. Titanium dioxide has a more helpful role in our environmental purification due to its nontoxicity, photo induced super-hydrophobicity and antifogging effect (Fujishima\& Honda, 1972). These properties have used to remove bacteria and harmful organic materials from water and air. Also in self-cleaning or self-sterilizing surfaces for places such as medical centers (Wong et al., 2008). The aim of this work, used the $\mathrm{TiO}_{2}$ nanoparticles/PVP films inhibit bacterial growth and biofilm formation in different surfaces like glass and plastic and catheters.

\section{MATERIAL AND METHODS}

\section{$\mathrm{TiO}_{2}$ nanoparticles/PVP Films}

Pure PVP and $\mathrm{TiO}_{2}$ nanoparticles doped PVP films have been prepared by employing solution-casting method (AlKadhemy, 2012; Nawaf, 2016). Hot distilled water $\left(\sim 55^{\circ} \mathrm{C}\right)(10 \mathrm{ml})$ was used to dissolve $(0.5 \mathrm{~g})$ from PVP) PVP is a 
granular powder with molecular weight $\left(\mathrm{M}_{\mathrm{w}}=40000 \mathrm{~g} / \mathrm{mole}\right)$ obtained from (Ourchem for Laboratory Use Only) this solution was magnetically stirred continuously for (30 min) until mixture became homogeneous viscous solution. Then it poured into glass and plastic petri dish with diameter $(10 \mathrm{~cm})$, keeps under room temperature $\left(\sim 30^{\circ} \mathrm{C}\right)$ for $(5$ days) to evaporate all solvent slowly, and obtained PVP thin film with thickness about $(0.00091 \mu \mathrm{m})$.In order to prepare $\quad \mathrm{TiO}_{2}$ nanoparticles/PVP composite films with two particle sizes for $\mathrm{TiO}_{2}$ nanoparticles (15.7 and 45.7) $\mathrm{nm}$; the amount of powder for each particle sizes as used $(0.01 \mathrm{~g})$ with (10 $\mathrm{ml})$ hot distilled water. $(6 \mathrm{ml})$ of this $\mathrm{TiO}_{2}$ nanoparticles solution was added to PVP solution to get $\mathrm{TiO}_{2}$ (15.7 and 45.7) $\mathrm{nm} / \mathrm{PVP}$ films. X-Ray Diffraction instrument used with type (SHIMADZU XRD - 6000) made in Japan to check XRD pattern. The instrument has the following specifications; Target is $\mathrm{CuK}_{\alpha}$, wavelength is $1.5406^{\circ} \mathrm{A}$, Current is 30 $(\mathrm{mA})$ and Voltage is $(40 \mathrm{KV})$.

\section{Coated of Catheters by $\mathrm{TiO}_{2}$ Nanoparticles with (PVP) Polymer}

The catheter pieces with length $(2 \mathrm{~cm})$ had coated in solution consisting of mixture (PVP) polymer with volume (10 $\mathrm{ml})$ and $\mathrm{TiO}_{2}$ with particle size $(15.7 \mathrm{~nm})$ with volume $(6 \mathrm{ml})$. Then put the catheter pieces in solution and left to dry for (7 days) and these were stored for (4) weeks to study the effect of storage on antibiofilm.
Antibacterial Effect of $(\mathrm{PVP}), \mathrm{TiO}_{2}$ Nanoparticles/PVP Films

Antibacterial activity of PVP films $(40000 \mathrm{~g} / \mathrm{mole})$ doped with $\mathrm{TiO}_{2}$ nanoparticles was studied against Staphylococcus aureus and Escherichia coli (Department of Biology / College of science / Mustansiriyah University/ Baghdad /Iraq). (PVP) and $\mathrm{TiO}_{2}$ nanoparticles/PVP were coated on plastic and glass plates, dried for (5) days. After drying the suspensions of bacterial isolates $10^{8} \mathrm{cell} / \mathrm{ml}$ are poured onto the film of plastic and glass plates, the control included plates with bacterial suspensions without (PVP) and $\mathrm{TiO}_{2}$ nanoparticles/ PVP films. All plates were incubated at $37^{\circ} \mathrm{C}$ for $24 \mathrm{~h}$. After the incubation $0.1 \mathrm{ml}$ of each dilution was taking, spread on Nutrient agar (Hi Media), incubated at $37^{\circ} \mathrm{C}$ for $24 \mathrm{~h}$ (Salman et al., 2014). The colonies were counted and the reduction of bacterial growth percentage was calculated using the following equation described by (Ghosh et al., 2010):

$R(\%)=\frac{(A-B)}{A} \times 100$

$\mathrm{R}=$ the reduction rate of bacterial growth, $\mathrm{A}=$ the number of colonies from control,

$\mathrm{B}=$ the number of colonies from coated plates with (PVP) or $\mathrm{TiO}_{2}$ nanoparticles /PVP films. 


\section{Antibiofilm effect of $\mathrm{TiO}_{2}$ Nanoparticles/PVP in Catheters}

The effect of (PVP) on biofilm formation of pathogenic bacteria in catheters was examined according to method of (Namasivayam et al., 2013) with some modification. Briefly, the coated pieces were immersed in $10 \mathrm{ml}$ of nutrient broth that inoculated with $S$. aureus and E. coli separately, incubated at $37^{\circ} \mathrm{C}$ for $24 \mathrm{~h}$. After incubation, the broth was decanted then all coated and uncoated catheter pieces (without any coated treatment) were stain for $30 \mathrm{~min}$ at room temperature with $(0.1 \mathrm{ml})$ crystal violet solution. Catheter pieces were washed with distilled water to remove the addition stain and washed three times with (95\%) ethanol, then ethanol was collected for measuring the absorbance of each piece at wavelength $(570 \mathrm{~nm})$ using spectrophotometer and inhibition of biofilm formation percentage was calculated as equation described as (Namasivayamet al., 2013):

\%Inhibition of biofilm formation=

$\frac{\text { ODincontrol-ODintreatment }}{\text { ODincontrol }} \times 100$

Control: uncoated catheters, treatment: coated catheters.

Measurement (LD50) of Polymer PolyVinylPyrrolidone (PVP) and $\mathrm{TiO}_{2}$ Nanoparticles

Six group of male Swiss mice (4 Weeks old), Weight approximately $20 \mathrm{~g}$, obtained from National Centre for Drug Control and Research (NCDCR). For each of (PVP) and $\mathrm{TiO}_{2}$ nanoparticles solution were daily administered orally for 10 days with $(0.1 \mathrm{ml})$ with a dose of $(5000$, 10000 , $15000,20000,25000,30000) \mathrm{mg} / \mathrm{kg}$ and with a dose of $(0.05-5.00) \mathrm{mg} / \mathrm{kg}$, respectively. Additional group of mice received normal saline $(0.1 \mathrm{ml})$ as a control group. At the end of dosing, all mice in all groups were examined, and the concentration which was killed half of animals was determined and considered LD50.

\section{RESULTS AND DISCUSSIONS}

The X-ray diffraction pattern of pure PVP powder is shown in fig. (1). The pure PVP scan shows very a broad diffraction peak around $2 \theta=20.9402^{\circ}$ corresponding d-spacing $4.23888 \quad \mathrm{~A}^{\mathrm{o}}$ with intensity (62) and peak with $2 \theta=$ $11.4695^{\circ}$ corresponding d-spacing $7.70892 \mathrm{~A}^{\circ}$ with intensity (36). That it confirms the amorphous nature of the prepared polymer film. That is conformity with either reported in literature (Rawat et al., 2012; Abdelghany et al., 2015). Table (1) illustrated some structural properties for pure PVP powder. Fig. (2- A, B) show the X-ray diffraction of pure $\mathrm{TiO}_{2}$ nanoparticles powder with two particles sizes, respectively. Strong diffraction peaks at $25^{\circ}, 48^{\circ}$ and $37^{\circ}$ indicating $\mathrm{TiO}_{2}$ in the Anatase phase, the intensities of XRD peaks of the sample reflects that the formed nanoparticles are crystalline (Saleh et al., 2014; Shehap et al.,2016). The intensity is increased with decreasing the Particle size, the particle size is nearly $(15.7 \mathrm{~nm})$ for fig. (2- A) 
and $(45.7 \mathrm{~nm})$ for fig. (2- B). Table (2 A, B) illustrated some structural properties for pure $\mathrm{TiO}_{2}$ nanoparticles with two particle sizes, respectively. When adding (6ml) of $\mathrm{TiO}_{2}$ with two particles sizes $((15.7 \mathrm{~nm})$ and $(45.7 \mathrm{~nm}))$ to PVP polymer are shown in figs. (3- A, B), respectively. From these figs., the effect of $\mathrm{TiO}_{2}$ nanoparticles increased on PVP polymer become semi-crystalline with decreasing the particle size, the intensity is increase with increasing of particle size of $\mathrm{TiO}_{2}$ nanoparticles and the particle size is nearly $(8.296,1.71554)$ with increasing with particle size. An average grain size of all samples was estimate from the X-ray line broadening analysis by formula of Scherer's (Nawaf, 2016; Al-Kadhemy\& Nawaf, 2017):

$D=\frac{0.9 \lambda}{\beta \operatorname{Cos} \theta}$

Where: $\lambda$ is the wavelength of $\mathrm{X}$-ray, $\beta$ is the value of FWHM and $\theta$ is Bragg's angle. nm for $\mathrm{TiO}_{2}(15.7,45.7) \mathrm{nm} / \mathrm{PVP}$ films, respectively. The peak $25.3424^{\circ}$ of $\mathrm{TiO}_{2}$ $(15.7 \mathrm{~nm})$ appear in $\mathrm{TiO}_{2}(15.7) \mathrm{nm} / \mathrm{PVP}$ film. The table (3- A, B) illustrated the magnitude of (20) for three high peaks with their intensities, FWHM, d-spacing and particle size. Then the particle size (D) from eq. (3), specific surface area (S) calculated from eq. (4) and dislocation density $(\delta)$ from eq. (5). It can be conclude from table (2- A, B) the specific surface area (S) and dislocation density $\quad(\delta)$ are decreasing

$$
S=\frac{6 \times 10^{3}}{D \cdot \rho}
$$

Where: $\mathrm{S}$ are the specific surface area and $\rho$ is the density of $\mathrm{TiO}_{2}\left(3.9 \mathrm{~g} / \mathrm{cm}^{3}\right)$ and $\mathrm{TiO}_{2}\left(4.23 \mathrm{~g} / \mathrm{cm}^{3}\right.$ for particle sizes (15.7 and 45.7) nm, respectively.

$\delta=\frac{1}{D^{2}}$

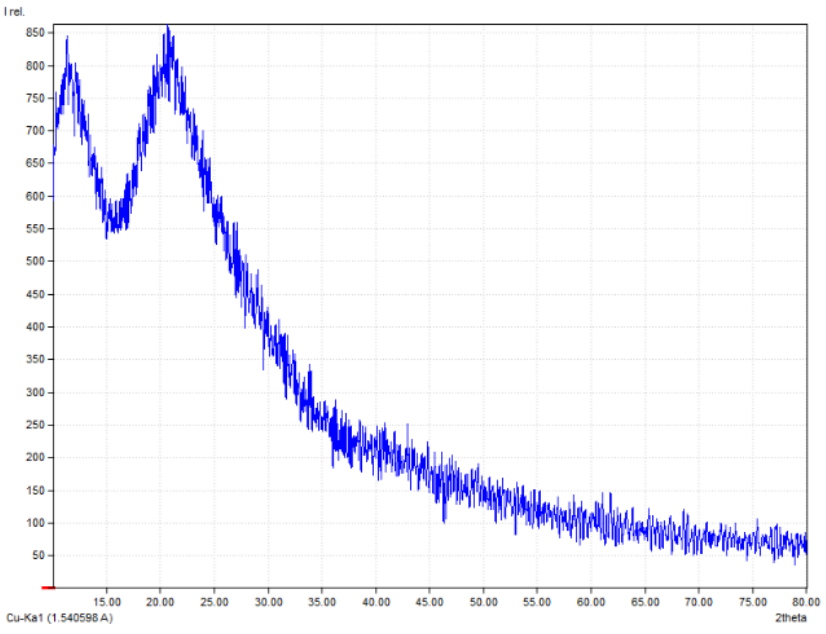

Fig. 1: XRD Pattern for pure PVP powder 
Table 1: XRD Parameters for Pure PVP Powder

\begin{tabular}{ccc}
\hline $\mathbf{2 \theta}$ (degree) & Intensity (counts) & $\mathbf{D}\left({ }^{\circ} \mathbf{A}\right)$ \\
\hline $\mathbf{1 1 . 4 6 9 5}$ & 36 & 7.70892 \\
$\mathbf{2 0 . 0 8 2 6}$ & 52 & 4.41792 \\
$\mathbf{2 0 . 3 4 1 8}$ & 52 & 4.36221 \\
$\mathbf{2 0 . 9 4 0 2}$ & 63 & 4.23888 \\
\hline
\end{tabular}
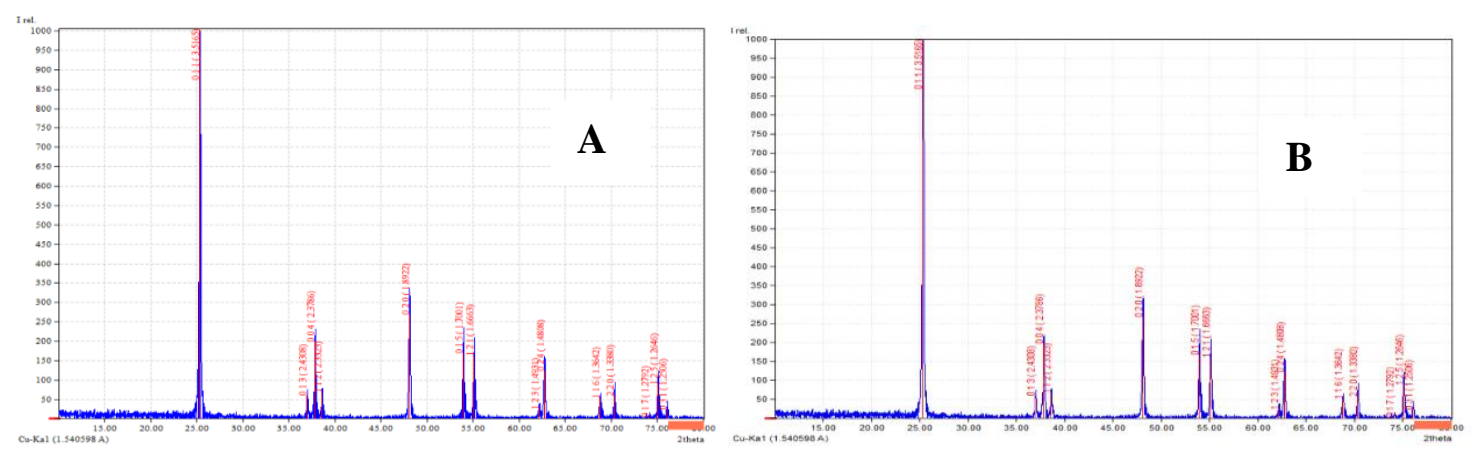

Fig. (2) XRD Pattern for Pure $\mathrm{TiO}_{2}$ nanoparticles powder with two particles sizes A- $(15.7 \mathrm{~nm}) \mathrm{B}-(45.7 \mathrm{~nm})$

Table 2- A: XRD Parameters for Pure $\mathrm{TiO}_{2}(15.7 \mathrm{~nm})$ Powder

\begin{tabular}{|c|c|c|c|c|c|c|c|}
\hline $2 \theta$ (degree) & $\begin{array}{l}\text { FWHM } \\
\text { (degree) }\end{array}$ & $\begin{array}{l}\text { Intensity } \\
\text { (counts) }\end{array}$ & d (̊̊) & hkl & $\mathbf{D}(\mathbf{n m})$ & $\begin{array}{l}\mathrm{Sx10} 0^{6} \\
\left(\mathrm{~m}^{2} \cdot \mathrm{g}^{-1}\right)\end{array}$ & $\delta \times 10^{6}\left(\mathrm{~m}^{-2}\right)$ \\
\hline 25.3424 & 0.54100 & 285 & 3.51165 & 011 & 15.1 & 0.1018 & 4.385 \\
\hline 36.9362 & 0.28000 & 16 & 2.43168 & 013 & 30.4 & 0.0505 & 1.082 \\
\hline 37.8804 & 0.67000 & 50 & 2.37321 & 004 & 12.6 & 0.1220 & 6.298 \\
\hline 38.7148 & 0.50000 & 12 & 2.32396 & 112 & 16.9 & 0.0910 & 3.501 \\
\hline 48.0716 & 0.59500 & 77 & 1.89120 & 020 & 14.7 & 0.1046 & 4.627 \\
\hline 53.9815 & 0.75000 & 39 & 1.69727 & 015 & 11.9 & 0.1292 & 7.061 \\
\hline 55.0311 & 0.73000 & 39 & 1.66735 & 121 & 12.2 & 0.1260 & 6.718 \\
\hline 62.0836 & 0.40000 & 12 & 1.49380 & 123 & 23.4 & 0.0657 & 1.826 \\
\hline 62.7034 & 0.76000 & 28 & 1.48052 & 024 & 12.3 & 0.1250 & 6.609 \\
\hline 68.8616 & 0.76000 & 10 & 1.36237 & 116 & 12.7 & 0.1211 & 6.200 \\
\hline 70.3212 & 0.64000 & 12 & 1.33763 & 220 & 15.2 & 0.1011 & 4.328 \\
\hline 75.0799 & 0.84000 & 16 & 1.26421 & 125 & 11.9 & 0.1292 & 7.061 \\
\hline
\end{tabular}


Table 2- B: XRD Parameters for Pure $\mathrm{TiO}_{2}(45.7 \mathrm{~nm})$ Powder

\begin{tabular}{cccccccc}
\hline $\begin{array}{c}\mathbf{2 \theta} \\
(\mathbf{d e g r e e})\end{array}$ & $\begin{array}{c}\text { FWHM } \\
(\mathbf{d e g r e e})\end{array}$ & $\begin{array}{c}\text { Intensity } \\
(\text { counts })\end{array}$ & $\begin{array}{c}\mathbf{D} \\
\mathbf{( \mathbf { A } )}\end{array}$ & $\mathbf{h k l}$ & $\begin{array}{c}\mathbf{D} \\
(\mathbf{n m})\end{array}$ & $\begin{array}{c}\mathbf{S x 1 0}^{\mathbf{6}} \\
\left(\mathbf{m}^{\mathbf{2}} \mathbf{. g}^{-\mathbf{1}}\right)\end{array}$ & $\begin{array}{c}\mathbf{\delta x 1 0} \\
\left.\mathbf{( m}^{\mathbf{2}}\right)\end{array}$ \\
\hline $\mathbf{2 5 . 3 7 1 2}$ & 0.21100 & 759 & 3.50773 & 011 & 39.5 & 0.0358 & 6.409 \\
$\mathbf{3 7 . 0 0 7 7}$ & 0.19670 & 46 & 2.42715 & 013 & 43.0 & 0.0329 & 5.408 \\
$\mathbf{3 7 . 8 5 1 5}$ & $0.2010 \square 0$ & 172 & 2.37496 & 004 & 41.9 & 0.0338 & 5.696 \\
$\mathbf{3 8 . 6 2 8 6}$ & 0.18750 & 48 & 2.32895 & 112 & 45.9 & 0.0308 & 4.746 \\
$\mathbf{4 8 . 0 9 6 7}$ & 0.19930 & 253 & 1.89027 & 020 & 44.6 & 0.0317 & 5.0272 \\
$\mathbf{5 3 . 9 4 3 4}$ & 0.20180 & 159 & 1.69838 & 015 & 44.4 & 0.0319 & 5.0726 \\
$\mathbf{5 5 . 1 2 0 1}$ & 0.21570 & 147 & 1.66487 & 121 & 42.2 & 0.0336 & 5.6153 \\
$\mathbf{6 2 . 1 6 9 1}$ & 0.17900 & 25 & 1.49196 & 123 & 52.2 & 0.0271 & 3.6699 \\
$\mathbf{6 2 . 7 4 4 3}$ & 0.20810 & 119 & 1.47965 & 024 & 45.1 & 0.0314 & 4.9163 \\
$\mathbf{6 8 . 8 0 0 9}$ & 0.21860 & 45 & 1.36343 & 116 & 44.2 & 0.0320 & 5.1186 \\
$\mathbf{7 0 . 3 4 2 2}$ & 0.19800 & 55 & 1.33728 & 220 & 49.9 & 0.0284 & 4.0160 \\
$\mathbf{7 5 . 0 9 1 0}$ & 0.214200 & 85 & 1.26405 & 125 & 47.3 & 0.0299 & 4.4696 \\
& & & & & & & \\
\hline
\end{tabular}
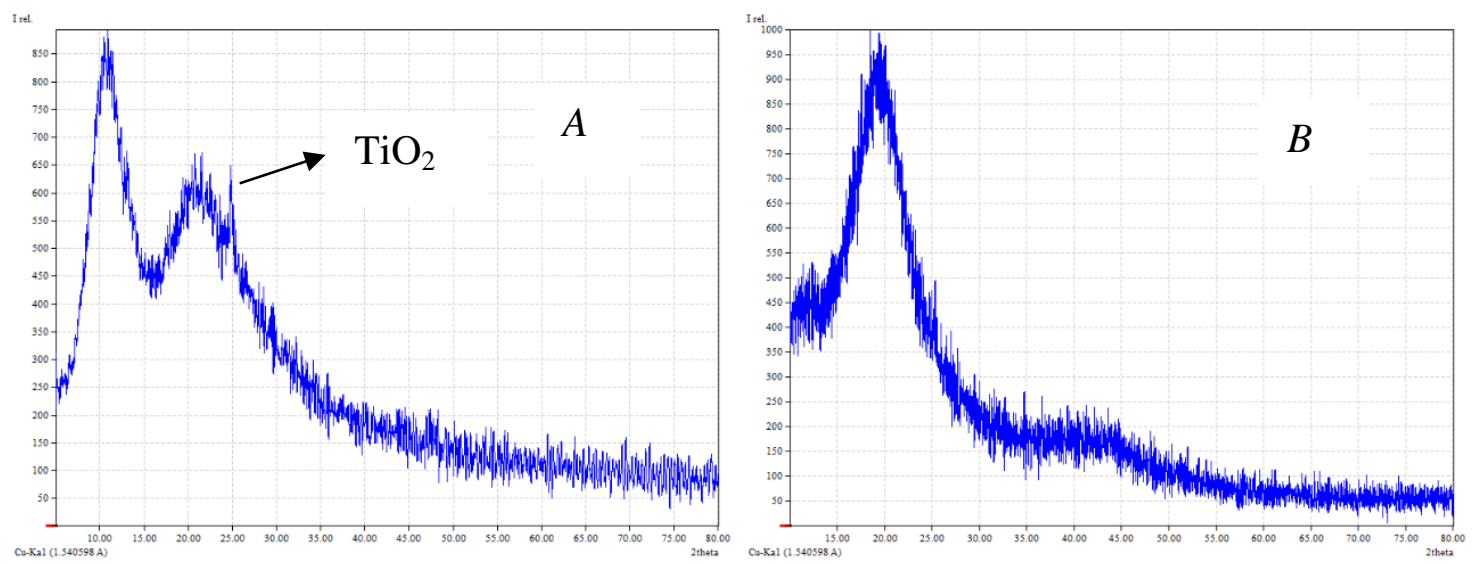

Fig. 3: XRD Pattern for $\mathrm{A}-\mathrm{TiO}_{2}(15.7 \mathrm{~nm}) / \mathrm{PVP}$ and $\mathrm{B}-\mathrm{TiO}_{2}(45.7 \mathrm{~nm}) / \mathrm{PVP}$ Films

Table 3- A: XRD Parameters for $\mathrm{TiO}_{2}(15.7 \mathrm{~nm}) / \mathrm{PVP}$ Film

\begin{tabular}{ccccc}
\hline $\mathbf{2 \theta}(\mathbf{d e g})$ & FWHM(deg) & Intensity(counts) & d (̊̊) & D(nm) \\
\hline 8.9490 & 1.36 & 35 & 9.87369 & 5.862 \\
10.4163 & 2.76 & 72 & 8.48589 & 2.891 \\
10.9527 & 3.18 & 69 & 8.07147 & 2.510 \\
24.9112 & 0.64 & 21 & 3.57145 & 12.838 \\
\hline
\end{tabular}


Table 3- B: XRD Parameters for $\mathrm{TiO}_{2}(45.7 \mathrm{~nm}) / \mathrm{PVP}$ Film

\begin{tabular}{ccccc}
\hline $\mathbf{2 \theta}(\mathbf{d e g})$ & FWHM(deg) & Intensity(counts) & $\mathbf{d ~ ( \mathbf { A } )}$ & $\mathbf{D}(\mathbf{n m})$ \\
\hline 19.3648 & 4.7 & 261 & 4.58003 & 1.71554 \\
20.5811 & 0.000 & 220 & 4.31203 & 0.00000 \\
21.8777 & 0.000 & 150 & 4.05931 & 0.00000 \\
\hline
\end{tabular}

Reduction of $S$. aureus and $E$. coli growth were tested by using PVP (Pure) and $\mathrm{TiO}_{2}$ nanoparticle $(45.7 \mathrm{~nm}) / \mathrm{PVP}$, $\mathrm{TiO}_{2}$ nanoparticle $(15.7 \mathrm{~nm}) / \mathrm{PVP}$ films on plastic and glass plates. The best results about reduction growth of $S$. aureus were obtained by PVP (Pure) film on glass plate reached to $(62.5 \%)$ and $\mathrm{TiO}_{2}(15.7 \mathrm{~nm}) / \mathrm{PVP}$ film on plastic reached to $(89.42 \%)$. And the best results for reduction growth of E.coli were observed for $\mathrm{TiO}_{2}(45.7 \mathrm{~nm}) / \mathrm{PVP}$ film reached to $(59 \%)$ and $\mathrm{TiO}_{2}$ $(15.7 \mathrm{~nm}) / \mathrm{PVP}$ film reached to $(100 \%)$ on plastic, while the best reduction for PVP(Pure) film on glass reached to (51\%) (Table4).

Table 4: Reduction of bacterial growth for $\mathrm{PVP}$ and $\mathrm{TiO}_{2}$ nanoparticles/PVP films

\begin{tabular}{|c|c|c|c|}
\hline Bacterial isolate & Treatment & Type of plates & Reduction of growth $(\%)$ \\
\hline \multirow{6}{*}{ Staphylococcus aureus } & PVP ( Pure ) & \multirow{3}{*}{ Plastic } & 60.89 \\
\hline & $\mathrm{PVP}_{+} \mathrm{TiO}_{2}(45.7 \mathrm{~nm})$ & & 55.1 \\
\hline & $\mathrm{PVP} \mathrm{TiO}_{2}(15.7 \mathrm{~nm})$ & & 89.42 \\
\hline & PVP ( Pure ) & \multirow{3}{*}{ Glass } & 62.5 \\
\hline & $\mathrm{PVP}_{+\mathrm{TiO}_{2}}(45.7 \mathrm{~nm})$ & & 69.55 \\
\hline & $\mathrm{PVP}_{+\mathrm{TiO}_{2}}(15.7 \mathrm{~nm})$ & & 86 \\
\hline \multirow{6}{*}{ Escherichia coli } & PVP ( Pure ) & \multirow{3}{*}{ Plastic } & 49 \\
\hline & $\mathrm{PVP}_{+} \mathrm{TiO}_{2}(45.7 \mathrm{~nm})$ & & 59 \\
\hline & $\mathrm{PVP}_{+} \mathrm{TiO}_{2}(\mathbf{1 5 . 7 n m})$ & & 100 \\
\hline & PVP ( Pure ) & \multirow{3}{*}{ Glass } & 51 \\
\hline & $\mathrm{PVP}_{+} \mathrm{TiO}_{2}(45.7 \mathrm{~nm})$ & & 49 \\
\hline & $\mathrm{PVP} \mathrm{TiO}_{2}(15.7 \mathrm{~nm})$ & & 69 \\
\hline
\end{tabular}

Table 5 illustrated the results for antibiofilm effect of $\mathrm{TiO}_{2} \quad$ (15.7 $\mathrm{nm}) / \mathrm{PVP}$ nanocomposite was studied against $S$. aureus and $E$. coli on catheters for different storage time. Results showed that one week of storage of coated catheters the biofilm inhibition ratio was $(29 \%)$, after two weeks of storage the inhibition ratio $(42.6 \%)$, and after the three weeks the inhibition ratio reached to $(56.21 \%)$. The best inhibitory effect obtained after four weeks of storage with inhibition ratio $(83.97 \%)$. The results for inhibition of biofilm for $E$. coli reached to $(22 \%)$ after one week, while two weeks of storage of catheters the inhibition ratio (30.9\%), and after the three week of storage reached to $(39.87 \%)$ and $(65.3 \%)$ after three and four weeks, respectively. 
Table 5: Inhibition of Biofilm Formation of $\mathrm{TiO}_{2}(15.7 \mathrm{~nm}) / \mathrm{PVP}$ against S.aureus and E.coli on Catheter after different times

\begin{tabular}{|c|c|c|c|c|}
\hline \multirow[b]{2}{*}{ Bacterial isolate } & \multicolumn{3}{|c|}{ Optical Density (O.D) } & \multirow[b]{2}{*}{$\begin{array}{c}\text { Inhibition biofilm } \\
\text { formation }(\%)\end{array}$} \\
\hline & Times & Control & $\begin{array}{c}\text { Coated } \\
\text { Catheter }\end{array}$ & \\
\hline \multirow{4}{*}{ Staphylococcus aureus } & (1) Week & 0.234 & 0.167 & 29 \\
\hline & (2) Week & 1.511 & 0.867 & 42.6 \\
\hline & (3) Week & 1.158 & 0.507 & 56.21 \\
\hline & (4) Week & 1.479 & 0.237 & 83.97 \\
\hline \multirow{4}{*}{ Escherichia coli } & (1) Week & 0.157 & 0.122 & 22 \\
\hline & (2) Week & 0.440 & 0.304 & 30.9 \\
\hline & (3) Week & 1.134 & 0.455 & 39.87 \\
\hline & (4) Week & 1.222 & 0.424 & 65.3 \\
\hline
\end{tabular}

The antibacterial activity is increase with decreasing the particle size of $\mathrm{TiO}_{2}$ nanoparticles with increasing the specific surface area and dislocation density. PVP is use as stabilizers; it has optical purity that authorizes the exploration of nanoparticle formation. PVP acts as a copping agent and the antimicrobial activity of PVP caused modification of nanoparticles, the polymer is most effective agent in the particles stabilization against aggregation (Jayaprakash et al., 2015). The metal oxides carry the positive charge while the bacteria carry negative charges; this causing electromagnetic attraction between bacterial surface and the metal oxides that caused oxidization and death of bacteria (Zhand\& Chen, 2009). They cause holes in the cell walls of bacteria, increasing permeability and death of cell (Holt \& Bard, 2005). The opposite charges of nanoparticles and bacteria are attributing to their bioactivity and adhesion due to electrostatic forces. Nanoparticles have larger surface area, which enhances bactericidal activity than the large size particles; they realize cytotoxicity to the bacteria (Bhupendra et al., 2009). Fungicidal and bactericidal effects of $\mathrm{TiO}_{2}$ on Pseudomonas aeruginosa, E. coli, Salmonella choleraesuis, Vibrio parahaemolyticus,

Listeriamonocytogenes, S. aureus, Diaport heactinidiae and Penicilliumexpansum have reported. The development of $\mathrm{TiO}_{2}$-coated or incorporated packaging of food and equipment of food preparing has also interest. (Chaweng kijwanich \& Hayata, 2008), concluded that the $\mathrm{TiO}_{2}$ coated film could reduce the bacterial contamination on the surface of food products and reduce the risks of bacterial 
growth on fresh-cut products. Inhibition activity of metallic nanoparticles on biofilm formation of bacteria has been importance, as the device-related infections that cause of morbidity and mortality in hospitalized patients (Delpozo et al., 2009). $\mathrm{TiO}_{2}$ nanoparticle had inhibitory effect on biofilm formation of multidrug resistant bacteria (Ibrahem et al., 2014). (Haghighiet al.2013) showed that $\mathrm{TiO}_{2}$ nanoparticles could kill Candida albicans and inhibit the formation of biofilm. Different shape and size of $\mathrm{TiO}_{2}$ nanoparticles can be used for the photo catalytic treatment of aqueous biofilm, pathogenic bacteria and multi drug resistant bacteria. MaurerJones et al. (2013) observed, significant changes in bacterial biofilm after treatment with $\mathrm{TiO}_{2}$ nanoparticles, nanoparticles caused altered gene expression relating to growth and biofilm formation. $\mathrm{TiO}_{2}$ nanoparticles leads to larger reduction of bacterial biofilm formation in the glass surface (Chorianopoulos et al., 2010). The $\mathrm{TiO}_{2}$ nanoparticles efficiently inhibited bacterial adhesion to acrylic surfaces as well as have strong antibacterial effect in the planktonic stage and biofilm formation (Bahador et al., 2014).

\section{Measurement (LD50) of (PVP) Polymer and $\mathrm{TiO}_{2}$ Nanoparticles.}

Toxicity of (PVP) and $\mathrm{TiO}_{2}$ nanoparticles was detect by determination the dose that cause death of $50 \%$ of laboratory animals. Results showed that no effect of (PVP) and $\mathrm{TiO}_{2}$ nanoparticles on the laboratory animals,
LD50 was (> 2000 and $>$ 5) $\mathrm{mg} \backslash \mathrm{Kg}$, respectively.

\section{CONCLUSION}

The effect of $\mathrm{TiO}_{2}$ nanoparticles on crystal structure of PVP polymer has investigated by $\mathrm{X}$-ray diffraction. There is some peaks from $\mathrm{TiO}_{2}$ appeared into structure of polymer. The $\mathrm{TiO}_{2}$ nanoparticles/ PVP films have antibacterial effect against bacteria in plastic and glass plates. In addition, it has antibiofilm effect in catheters.

\section{REFERENCES}

Abdelghany A.M., Meikhail M.S., Abdellrazek E.M. \&Abond M.M. (2015). Spectroscopic inquest of $\mathrm{CdS}, \mathrm{PbS}$ and $\mathrm{ZnS}$ Doped PVP composite: A Density Functional Theory Approach.Research Journal of Pharmaceutical, Biological and Chemical Sciences, 6(3): 1686-1697.

Alivisatos

A. $\quad \mathrm{P}$

(1996).

SemiconductorClustors,

Nanocrystals and Quantum Dots.Science. 271(5251): 933937.

Al-Kadhemy M. F. H., Hussein R., AlZuky A. A. D.(2012).Analysis of absorption spectra of styrenebutadiene in toluene, journal of physical science, 23(1):1-12.

Al-Kadhemy M. F. H., Nawaf S. H.(2017). Nonlinear and linear optical properties of Eosin B dye-

$\mathrm{AgNO}_{3}-$ 
Polyvinylprrolidone films, Material focus ,6(1): 54-62. Basf, (2009). PVP and more ... Luvitec, Luvicross and Collacral, Brochure.

Bahador A., Ghorbanzadeh R. \&Kassaee M.Z. (2014). Antimicrobial Activity of Acrylic Resins with In-Situ Generated Nanosilveron Cariogenic Planktonic and Biofilm Bacteria.Int. Res. J. Biological Sci. 3(4): 38-46.

Bhupendra Ch., AnJana K. V., Nidhi A., Upadhyay R.V.,\& Mehta R.V. (2009). Enhanced Antibacterial activity of biofunctional $\mathrm{Fe}_{3} \mathrm{O}_{4}$ Ag Core-Shell nanostructures. Nano Res. 2: 955-965.

Chawenqkijwaich C. \&Hayata Y.(2008). Development of $\mathrm{TiO}_{2}$ powdercoated food packing film and its ability to inactivate Escherichia coli in vitro and in actual tests. Int. J. Food Microbiol. 123(3): 288-92.

Chorianopoulos N.G., Tsoukleris D.S., Panagou E.Z., Falaras P. \&Nychas G. (2010). Use of titanium dioxide $\left(\mathrm{TiO}_{2}\right)$ photocatalysts as alternative means for Listeria monocytogenes biofilm disinfection in food processing. Food Microbiol. 28: 164-170.

Chowhan, Z.T., Amaro, A.A., \&Ong, J.T.H., (1992). Punch Geometry and Formulation Considerations in Reducing Tablet Friability and Their Effect on in vitro Dissolution. J. Pharm. Sci. 81: 290-294.
Del-pozo J.,Crumlish M., Ferguson H.M. \& Turnbull J.F. (2009). Aretrospective Cross- Sectional Study on Candidatusarthromitus associated rainbow trout gastroeuterities (RTGE) in the UK. Aquacultrue 290: 22-27.

Fujishima A. \& Honda K., (1972). Electrochemical Photolysis of Waterata Semiconductor Electrode.Nature 238: 37.

Ghosh, S., Upadhay,A., Singh,A. \& Kumar, A. (2010). Investigation of antimicrobial activity of silver nano particle loaded cotton fabrics, which may promote wound healing. International Journal of Pharma and Bio Sciences.1 (3):1-10.

Haghighi Mood S, Golfeshan AH,Tabatabaei M, SalehiJouzaniGh, NajafiGh, Gholami M,\& Ardjmand M. (2013). Lignocellulosic biomass to bioethanol; a comprehensive review on pretreatment. Renew Sust. Energ. Rev. 27: 77-93.

Holt K.B.\& Bard A. J. (2005)Interaction of silver (1) ions with the respiratory chain of Escherichia coli:an electrochemical and scanning electrochemical microscopy of micro molar Ag. Biochemistry. 44(39):13214-23.

Ibrahem K.H., Salman J.A.S \& Ali, F.A. (2014). Effect of Titanium Nanoparticles Biosynthesis by Laactobacilllus Crispatus on Urease, Hemolysin and Biofilm Forming by Some Bacteria Causing Recurrent UTI in Iraqi Women. European Scientific Journal 10(9): 324-338. 
Jayaprakash, N., Vijaya,J.J. \&Kennedy, L.J. (2015). Microwave-Assisted Rapid Facile Synthesis, Characterization, and Their Antibacterial Activity of PVP Capped Silver Nanospheres, Synthesis and Reactivity. Inorganic, Metal-Organic, and Nano-Metal Chemistry. 45(10): 1533-1538. Jun, Y.B., Min, B.H., Kim, S.I., Kim\& Y.I.J. (1989). Preparation and Evaluation of Acetaminophen Tablets. Kor. Pharm. Sci. 19: 123-128.

Kadajji V. G. \&Betageri G. V. (2011).Water Soluble Polymers for Pharmaceutical Applications.Polymers 3: 19722009.

Maurer-Jones M.A., Gunsolus I.L., Murphy C.J.\& Haynes C.L. (2013). Toxicity of engineered nanoparticles in the environment. Anal Chem.85: 3036-3049.

Nawaf S. H. (2016). Physical andNonlinear Optical Properties of PVP Polymer doped by Silver Nitrate and Nano Silver -Eosin B, M.S.C. Thesis, College of Science, Al-Mustansiriyah University.

Namasivayam, S.K.R. and Roy, E. A,(2013). Enhanced Antibiofilm Activity of Chitosan Stabilized Chemogenic Silver Nanoparticles Against Escherichia coli Int. J. of Sci. and Res.Publications. 3(4), 1-9.

Rawat A., Mahavar H.K., Chauhan S.,Tanwar A. \& Singh P.J. (2012). Optical band gap of polyvinyl pyrrolidone/ polyacrilamide blend thin films.
Indian Journal of pure \& Applied Physics 50: 100-104.

Sinchalpanid, N.\& Mitrevej, A. (1993). Comparative Evaluation of Hydroxypropyl Cellulose and Povidone in Paracetamol Tablet Formulations. Mahidol J. Pharm. Sci. 20: 33-39.

Saleh A.F., Jaffar A.M.,Samoom N.A. \& Mahmmod M. W. (2014). Effect Adding PVA Polymer on Structural and Optical Properties of $\mathrm{TiO}_{2}$ Thin Films. Journal of Al-Nahrain Sci. 17 (2): 116-121.

Salman, J.A.S., Al Kadhemy, M.F.H., Jaleel, M.S. \&Abdal, A.KH. (2014). Effect of PVA, PVA/Biosurfactant on Some Pathogenic Bacteria in Glass and Plastic Plates. International Journal of Current Microbiology and Applied Science. 3(10): 301309.

Shehap A.M. \&Akil D.S. (2016). Structural and optical properties of $\mathrm{TiO}_{2}$ nanoparticles/PVA for different composites thin films Int. J. Nanoelectronics and Materials. 9:17-36.

Wong M.S, Hsu S.W, Rao K.K\& KumarC.P. (2008).Influence of crystallinity and carbon content on visible light photocatalysis of carbon doped titania thin films.Journal of Molecular Catalysis A: Chemical. 279 (1): 20-26.

Zhand. H\& Chen G.P. (2009). Antibacterial activities of $\mathrm{Ag} / \mathrm{TiO}_{2}$ nanocomposite powders synthesized by a one-potsol-gelmethod. Envirron sci. Technol. 34(8):

2905-1 
Malaysia Journal of Science 36 (3):132-144 (2017) 